\title{
Deviant Detectives in the Scandinavian Welfare State: \\ The Girl with the Dragon Tattoo and The Bridge.
}

\author{
Jakob Stougaard-Nielsen (UCL)
}

\begin{abstract}
:
Stougaard-Nielsen explores how the deviant, female detective in Scandinavian crime fiction is used to engage audiences in considerations of social trust and equality in the contemporary welfare state. Drawing on examples of neuro-diverse detectives in Stieg Larsson's The Girl with the Dragon Tattoo and the Tv-serial The Bridge, the chapter focuses on fictional representations of autism, and considers the apparent paradox that socially dysfunctional and non-empathetic detectives, such as Lisbeth Salander and Saga Norén, have become globally celebrated as heroines who embody social justice and egalitarianism. Stougaard-Nielsen argues that to understand the appeal of the deviant detective, we need to understand their representation with a more nuanced notion of empathy and in the context of an ethos of statist individualism inherent to the Scandinavian welfare state.
\end{abstract}

Keywords: Scandinavian crime fiction, autism, post-welfare state, empathy, Lisbeth Salander, Saga Norén

Index terms: Scandinavian crime fiction, autism (Asperger's syndrome), neurodiverse, detective (deviant), welfare state (Scandinavian), post-welfare state, empathy, felt knowledge, Lisbeth Salander (The Girl with the Dragon Tattoo), Saga Norén (The Bridge), statist individualism

The global success of Scandinavian crime novels, movies and TV series, such as The Girl with the Dragon Tattoo (2005), The Killing (2007, 2009, 2012) and The Bridge (2011, 2013, 2015, 2018), has, to a large extent, depended on, what are generally perceived to be, their refreshingly 'new', mysteriously unsociable and unsentimental female heroines: the gothhacker Lisbeth Salander, and the socially dysfunctional police detectives Sarah Lund and Saga Norén. In bestselling crime novels, blockbuster film adaptations, globally disseminated TV series, novelisations and transnational TV adaptations, the deviant detectives of 'Nordic 
Noir' ${ }^{1}$ (deviance understood here as behaviour that violates generally accepted norms in a group or society) have infused the crime genre with recognizably new and complex characters, whose personal struggles, especially difficulties with interpersonal relationships, in intricate ways, complement the violent crimes they are investigating and the troubled societies in which they navigate.

These female investigators and detectives, to which we can also include nonScandinavian ones, such as the bi-polar Carrie Mathison in the US TV series Homeland, have not only attracted a wide audience because they provide novel characters who deviate from the gender norm of the still male-dominated global genre of crime fiction; that is, they take on characteristics usually associated with hard-boiled male detectives and refuse to conform to generic female stereotypes such as the classic femme fatale or the passive victim. Salander, Lund and Norén, in fact, also deviate from the late-modern tradition of feminist crime fiction in Scandinavia and beyond. It is particular to these Scandinavian female detectives that they are presented as socially dysfunctional and even recognizably neurodiverse, somewhere on the autism spectrum. Such more or less explicit diagnoses dissociate them from normative feminine characteristics such as being caring, empathetic mothers, wives, companions and co-workers.

Now forming a veritable genre trait in 'Nordic Noir', it is arguably still unclear why this troubled deviant female detective - deviant both in terms of genre expectations and in contrast to a perceived notion of 'neuro-normalcy' - has attracted a wide global audience, and why particularly Scandinavian narratives return to this character or trope. That the deviant detective amounts to a surprising cultural obsession was reflected in a Danish newspaper article that concluded: 'We are obsessed with emotionally frigid masculine women: Why is the brilliant, sickly woman suddenly everywhere?' (Brovall, 2013). In the UK, taking stock of the British fascination with female protagonists in Scandinavian TV series, The Guardian produced the satirical Venn diagram, 'Anatomy of a ScandiProtagonist', which illustrated traits shared between Lund, Norén and Birgitte Nyborg (the main character in the Danish political TV drama Borgen), including their shared penchant for 'trouble with society' and 'trouble with social skills'.

In the following, I shall explore what function the detective's neurodiversity, her deviance from societal, gendered and generic norms, has in Scandinavian crime narratives, and attempt to answer why this detective has generated such a wide interest. These stories do

\footnotetext{
${ }^{1}$ Deviance here understood as behaviour that violates generally accepted norms in a group or society.
} 
present stock typologies of psychopathic serial killers and other mentally disabled criminals, meant to excite fear and suspense, representing transgressions of societal norms to be reined in by maverick hard-boiled detectives. However, my assumption is that their preoccupation with mentally and socially diverse or disabled heroines inserts a dominant sentimental storyline into the melodramatic crime narrative. It is the sentimental personal stories of the deviant detectives, which make these narratives well-placed to explore 'the pleasures and challenges of community - with sentimental fiction supplying the original template for that community', following Leonard Cassuto's observation that 'inside every crime story is a sentimental narrative that's trying to come out' $(2009$, p. 3).

I shall argue that the deviant detective, by embodying a gendered conflict between normative empathy and social dysfunction, has become a seminal figure for exploring contemporary conflicts in the neoliberal welfare state through the staging of sentimental negotiations of interpersonal trust on a background of wider social dissolution and violent crimes. Trust, in particular, can be seen as a founding principle and the very kit that holds together the Scandinavian welfare state (Rothstein, 2005). From my perspective, it is exactly a perceived threat to the cohesion of these welfare societies (and societies beyond the Scandinavian region) that has made interpersonal and social trust a central preoccupation in the hard-boiled, sentimental mode of 'Nordic Noir' - the 'brilliant, sickly woman' is seemingly everywhere, I argue, because she is used as a figure through which to explore the 'pleasures and challenges' of community, interpersonal and social trust.

\section{The Rise of the Deviant Detective in the Post-Welfare State}

As generic types, especially Salander and Norén challenge, on the one hand, the traditionally gendered image of women detectives, and are, on the other, deviating from the collectivist values and social norms associated with the Social-Democratic Scandinavian welfare state at least in its persistent early-twentieth-century image of a 'people's home' (folkhem). Swedish Prime Minister Per Albin Hansson's vision in 1928 of an idyllic Swedish 'people's home', which would replace a society mired in class divisions, had, in the eyes of many, materialised in a near-perfect nation-family characterised by equality, mutual understanding, low unemployment and a general optimism for the future following steady economic growth during 'the record years' in the decades following the Second World War.

As I have discussed elsewhere, Scandinavian crime fiction at the turn of the millennium operates within a neoliberal post-welfare state, nostalgic about a utopian golden age and critical of the perceived dissolution of trust and social responsibility (Stougaard- 
Nielsen, 2017). In popular crime narratives since the 1990s, detectives may successfully bring criminals to justice, yet they are troubled by a sense of uncontrollable and irreversible social and moral decay to which they themselves remain mere spectators, leaving them in a firm grip of melancholia. Henning Mankell's Kurt Wallander is a well-known example of this Scandinavian detective. He is a witness to the deterioration of the welfare state and his own family, while maintaining the hope that he might help restore both to their idyllic past.

Scandinavian crime fiction is commonly considered obsessed with domestic realism and social critique, with morose detectives rummaging in the shadows of the otherwise wellfunctioning welfare states of Denmark, Finland, Iceland, Norway and Sweden. The moniker 'Nordic Noir', as used to describe the dark, cold, indignant and melancholic crime narratives, which have come out of Scandinavia in the twenty-first century, is embodied in the stereotypical Scandinavian male detective.

It has, indeed, become a cliché of the genre that at first male and, more recently, female investigators need to struggle with and refract their conflict-ridden private lives through their investigation of violent crimes and crumbling societies. Mankell's Wallander, Sjöwall and Wahlöö’s Martin Beck, Gunnar Staalesen's Varg Veum, Stieg Larsson's Mikael Blomkvist, Arnaldur Indridason's Erlendur and Håkan Nesser's Van Veeteren are all male detectives who must cope with strained family relations. Some are prone to heavy drinking and melancholia, and they are all unhealthily obsessed with police work.

What has been described as the male-dominated 'ulcer school' has been matched by the dramatic rise in narratives featuring female sleuths in the new millennium, such as Liza Marklund's Annika Bengtzon and Elsebeth Egholm's Dicte Svendsen, both maverick journalists whose inability to maintain a balanced family life and their troubled interpersonal relations stand in stark contrast to their investigative abilities. However, in their different ways they are all searching for meaningful interpersonal ties, homes and relationships at the same time as the crimes they investigate expose such ties, social norms and institutions as at best fragile if not outright dangerous. Such narratives featuring postfeminist investigators often centre on their (in)abilities to juggle their private lives as wives and mothers with professional ambitions in still male-dominated professions such as journalism. These are, I would argue, essentially sentimental stories about persistent gender inequalities in the modern welfare state and attempts to establish new norms for collective feminine identities. Their detectives are, according to Nete Schmidt (2015, p. 436), 'alienated as regards the expectations of a normal feminine/female life, and they constantly battle the threat of being 
labelled as deviants in trying to overcome the dichotomous vulnerability expressed in their private versus official existence'.

Marklund's Bengtzon, for instance, was a new heroine in Scandinavian crime fiction in the late 1990s. Her Sweden is not a 'lost paradise' like Wallander's, but one in which individual idealism and progress may lead to a brighter future, at least for a woman, who is not afraid to take on the patriarchal society, even if it means to live with the anxiety of not quite living up to the ideals and persistent norms of motherhood. In this way, Marklund's Bengtzon series may be read as an example of a post-welfare state crime novel as it appears to be accepting that the big collective project of the 'people's home' has shattered into 'countless small and individual' projects (Svensson, 1999, p. 182).

A similar critique of 'covert neoliberalism' has been levelled against Stieg Larsson's hyper-individualist heroine, Lisbeth Salander, whose private vendetta against misogynist rapists and serial killers could appear to merely reproduce the symbolic violence of the individualist and competitive society, which she is seemingly called upon to destroy (Stenport and Alm, 2009). According to such a view, the social criticism we have come to expect of Scandinavian crime fiction has dissipated in the hands of crime writers in the early years of the twenty-first century, where collective social responsibility is subordinated the aspirations of the individual, who has learned to 'perform' successfully on the stage of the narcissistic, neoliberal state. However, while the deviant, neurodiverse detectives may suggest a continuation of this tradition of individualistic, aspirational female sleuths, her condition signals a more complicated - at times intimate, at other times critical - relationship between the welfare society and the individual as represented in crime fiction.

\section{Nordic Narratives of Proximity}

The close relationship between the police procedural and the normative contrasts between social order and deviance in the welfare state is perhaps best illustrated in a rare Danish serial-killer TV-crime series, wherein we come closer to what is truly novel about the rise of the deviant female detective. In Den som draber (TV2, 2011; Those who Kill, ITV3, 2012), written by the bestselling crime writer Elsebeth Egholm, the police detective Katrine Ries Jensen is a recognizable Scandinavian detective with a dedication to her work bordering on monomania. In the police unit, she is under pressure to prove herself as a deputy chief inspector surrounded, as she is, mostly by male colleagues with a male chief inspector. Together with the obsessive forensic psychologist, Thomas Schaeffer, they investigate 
several brutal serial killings over ten episodes in recognizable contemporary Danish environments.

However, as the creators' description of the series intimates, the setting is to be understood as a near-future, dystopian vision of a wrecked Danish welfare state, where the hitherto almost non-existent psychotic serial killers now roam the streets due to a breakdown in welfare services:

\begin{abstract}
Those who Kill is a crime series about a violent criminal who is surrounded by fear and mystique the serial killer. Up until now, we have been able to curtail their activities with early - and effective - interventions via the safety net of a comprehensive social welfare system in Scandinavia. But times have changed. Borders have opened up, social welfare is in decline, and slowly but surely the whole system has become imbued with a sense of resigned impotence and callous disregard for those it once sought to rescue. The rifts in the net have become so large that bigger fish are slipping through the mesh, and as a result, a new type of crime is starting to burgeon - killings not grounded in traditional motives and patterns of behaviour. You need a very particular kind of person to catch the serial killer; someone who knows and understands the killer's dark side, and the fantasies that plague him - someone like our two lead characters, Deputy Chief Inspector (DCI) Katrine Ries Jensen and forensic psychiatrist Thomas Schaeffer [...], who in very different ways each possess a deep psychological understanding that connects them to the killer's victims and to the killer himself, driving them to pursue each case to the end of the line, again and again. (Trust Nordisk, Those who kill Pressbook)
\end{abstract}

Those who Kill is arguably the most explicit example of how contemporary Scandinavian $\mathrm{TV}$-crime drama foregrounds the connection between social deviance and the protection of the welfare state, wherein the serial detective is intimately 'connected' to the monstrous serial killer. It is, to use Gill Plain's (2001, p. 223) term, an example of a 'narrative of proximity': 'a discourse in which the other proves uncomfortably similar to the bourgeois individual self’. Yvonne Leffler (2013, pp. 52-3) has also noticed this trait in recent Scandinavian crime fiction explaining that:

[t]he reason why the detective eventually catches the criminal is their similarity. The investigation requires a detective almost as obsessed, guilty, and contaminated as the killer; that is, a detective who has experienced, or is emotionally involved in, something similar to what made the killer into a killer. Therefore, at times, the story is just as much about the detective's conflicts and emotional fragmentation as it is about the crime that is to be solved.

This motif where, for instance, the 'murder stirs up the investigator's hidden memories, personal secrets, emotional traumas, and even questions concerning their own origins', is particularly prevalent in crime stories with a female protagonist, Leffler (2013, p. 53) argues, 'as if it is possible to dig deeper into the consequences of crime, especially questions of victimhood and sexual violence, through a female investigator'.

The gendered proclivity for proximity between female investigator and criminal may also stem from its connection to a traditional trope in crime fiction where the approximation has tended to be between detective and victim. Kathleen A. McHugh (2018, p. 537) has 
argued that the crime genre traditionally exhibited a 'problematic conflation of the female detective with the usually female (or feminized) victim', and any progressive renewal of gender norms in the crime novel with a female protagonist and the female detective's agency itself 'is offset by "archaic" representations of victimized femininity'. McHugh suggests that, by reaffirming gender norms of the objectified feminine victim through narratives that sport acting female investigators, contemporary TV drama achieves wide appeal by staying both 'current and familiar'.

As mavericks with strained if not directly adversarial relations to their families and the wider society, these deviant detectives appear the least likely to pose as a bulwark against challenges to the ingrained social norms and values of the 'people's home'. Figuratively and literally, they appear incapable of having a 'home' in the first place. In The Girl who Played with Fire, Lisbeth Salander leaves boxes of flat-packed IKEA furniture for her new apartment unopened, illustrating her inability of creating a 'home' for herself; in the first season of The Killing, Sarah Lund repeatedly postpones her departure from the Danish police to join her Swedish partner in their new home, due to her obsession with the case of a murdered young woman; and Saga Norén's apartment, in the first season of The Bridge, mostly doubles as her solitary work place.

That detectives deviate from the norms and collectivist values of the wider society is significant as the Scandinavian police procedural, according to Michael Tapper (2011, p. 38), 'is different from other genres, because when a police man is confronted with the criminal, the crime is not only an individual conflict but also involves a moral nature, an ideological conflict between individual and society, normality and deviance'. The detective as a guarantor of social values is challenged when such a detective embodies deviant traits that place her at odds with the norms of the wider society. Tapper is here in line with John Scaggs' (2005, p. 99) identification of a common trait in the subgenre of the police procedural, the dominant sub-genre in Scandinavian crime fiction, wherein imbuing the killer with monstrous (deviant) traits isolates the criminal's instincts 'from all social, political or economic causes', exonerating the social order of all responsibility regarding its 'deviant' citizens $[\ldots][\mathrm{I}] \mathrm{t}$ returns to the clarity of black and white distinctions in which evil $[\ldots]$ is a pure "other" that is uncomplicatedly monstrous and inhuman'. The detective in the police procedural, then, comes to function as 'a powerful weapon of reassurance in the arsenal of the dominant social order' (Scaggs, 2005, p. 98).

The deviant detectives, however, question generic black-and-white differentiations between 'social order' and 'deviant citizens', self and other, from within the genre that 
traditionally has functioned as a re-affirmation of 'normalcy' against the threat of the deviant other. In a crime series such as The Bridge the 'borders' between social order and monstrous other, between 'normalcy' and deviance, are repeatedly blurred, not only as a consequence of the socially dysfunctional detective, but also through crime plots where, apparently, 'socially conscious' criminals are seeking to re-establish the state's social responsibilities through killings meant to draw attention to the state's inability to prevent social 'ills' such as homelessness, animal welfare, pollution, prostitution and gender inequality.

In the case of the neurodiverse detectives Salander and Norén, to whom I shall now turn, one could add that it is partly their gender but especially their neurodiverse traits and behaviours that make them simultaneously 'current and familiar' to a global crime fiction audience. The deviant female detective is a paradox, particularly in the context of the Scandinavian welfare societies, wherein the state and its representatives are traditionally viewed as guarantors of collectivist ideals and social empathy, but also in the context of the genre itself, where, according to Suzanne Keen (2007, p. 10), lack of empathy usually 'spells social problems, danger to others, criminality, and inhumanity'; in other words, traits usually associated with deviant criminals such as serial killers. According to McHugh (2018, p. 539), 'the neurodiverse female detective, with a compromised relationship to empathy, presents a special case that nevertheless reaches back to the genre's literary origins'.

The neurodiverse or dysfunctional detective has a longstanding tradition including seminal examples such as Dupin and Sherlock Holmes, the latter of whom psychologists and fans have diagnosed as autistic. This tradition, according to McHugh (2018, p. 539), 'includes asocial, alcoholic and workaholic, and physically disabled detectives and those who are neurodiverse'. To this list belong also the deviant detectives in Those Who Kill and Homeland, who 'exhibit what the neurodiverse community refers to as the savant stereotype; that is, their protagonist's disorder produces their genius.' In the Scandinavian tradition, the savant detective has relatives in Mankell's Wallander and Sjöwall and Wahlöö's Beck whose 'dysfunctionalities seem to be the very reason for [their] potency.' As argued by Camilla Schwartz and E. Ann Kaplan (forthcoming, p. 4): '[t]hese male detectives [...] are brilliant not in spite of their outsider position but because of it'. Though related to savant male detectives, the empathic dysfunctions shared by savant female detectives insert them in a particularly troubled position in relation to the societal norms they are presumably called to uphold.

\section{Diagnosing The Girl with the Dragon Tattoo}


Stieg Larsson's Män som hatar kvinnor (2005, The Girl with the Dragon Tattoo, 2008) has been read as an example of socially conscious Scandinavian crime fiction in its depictions of a seemingly realistic Swedish social and geographical environment. The novel's epigraphs reference statistical data of men's violence against women, which call into question the progressive egalitarianism of the Swedish welfare state and lend a degree of authenticity to the crime novel. Widespread violence against women is depicted as having deep roots in the past represented by Swedish Nazi serial killers and contemporary amoral representatives of the patriarchal welfare state, including lawyers and doctors, who abuse their roles as guardians and protectors of a traumatized and alienated, yet immensely resourceful and resilient, young woman, Lisbeth Salander, the girl with the dragon tattoo.

In the novel, as a consequence of her work as an investigator for a private security firm, Salander is drawn into the journalist Mikael Blomkvist's investigation of the mysterious disappearance of a young woman from the industrialist Vanger family several years in the past. Parallel to the melodramatic crime narrative, the novel's central focus on Salander's personal story forms a recognizable 'narrative of proximity', in Leffler's (2013, p. 53) sense, in that the disappearance and suspected murder 'stirs up [Salander's] hidden memories, personal secrets, emotional traumas, and even questions concerning [her] own origins': her traumatic childhood with a violent father, whose identity has been kept a secret by an illicit cell in the police force; Salander's attempted murder of him, provoked by his repeated violence against her mother; her own repeated institutionalizations as a young girl due to 'diagnoses' of social and mental dysfunctions, and her placement under guardianship - at first with Palmgren, a lawyer of moral integrity, who falls ill and is replaced by Bjurman, a sadistic lawyer bend on denying Salander her personal freedom. Her traumatic childhood is presented as the direct cause of her introvert behaviour, anti-social appearance and her deep suspicion of authorities, and is at the same time her prime asset and motivation for bringing the rapist serial killers of young women to justice by whatever means necessary. According to Leffler (2013, p. 59),

[Salander] rejects all established relationships, social identities, and traditional contracts of employment. She is a fusion of incompatible gender roles, as she is an extremely clever researcher and a physically fit fighter at the same time as she is a tiny woman and a vulnerable social outcast. As a combination of threatened victim, revenging computer hacker, and feisty avenger she is paying back for her lost childhood.

She is the prototype savant detective, whose exceptional investigative skills as a hacker pertain to her social isolation. Her interpersonal dysfunctional behaviours have deep roots in 
a traumatic childhood, experiences of violence and incarceration, and in 'diagnoses' of mental dysfunctions, which leave her vulnerable to exploitation from a state-appointed guardian. In the now famous scene, where Salander reclaims her independence and takes her revenge on Bjurman by documenting his rape and where she tattoos the words 'I AM A SADISTIC PIG AND RAPIST' into his chest, the narrator explains that in Sweden guardianship has mostly been used in cases involving mental illness. We learn about Salander's history with social and psychiatric guardianship. When she was thirteen, she was committed to a psychiatric ward for children. She was considered emotionally disturbed, violent, and unwilling to discuss her emotions, which made it difficult to diagnose her mental deficiencies. In a report used to justify her being committed and later to place her under guardianship, she is described as lacking self-awareness, she was introvert, lacked empathy, was socially inhibited with psychopathic tendencies and had difficulty cooperating - a list of deficiencies which is also a rather precise description of the stereotypical deviant detective in 'Nordic noir'.

The guardian is a central figure in The Girl with the Dragon Tattoo as Salander's two guardians come to represent extremes of the paternalistic welfare state: Bjurman not only violates her body but also takes away her independence when he limits her access to her bank account. He is contrasted to Palmgren who embodies traditional welfarist values and only accepts his guardianship if Salander agrees and decides to put her trust in him. The crime novel does not provide a 'state solution' to clearing Salander of her diagnosis, or a desire to 'normalize' her gender position, neither is her independence immediately reclaimed as a result of her contribution to the successful investigation into Harriet Vanger's disappearance. Salander's struggle to reclaim her independence from her state-appointed guardian in a dysfunctional, violent and corrupted welfare system is mostly concerned with her access to independent funds. When she cannot be liberated through the corrupt legal system, she takes the law into her own hands and secures access, through threats and hacking, to illicit funds placed conveniently in off-shore accounts. It is, therefore, tempting to read Salander's deviance as proximate to the socially dysfunctional neo-liberal welfare state.

However, in a crime novel comprising a host of genres including financial thriller, locked-room mystery, serial killer fiction and police procedural, the embedded sentimental narrative largely pertains to the developing relationship between Lisbeth Salander and Mikael Blomkvist, which hinges on her ability to develop interpersonal trust. Towards the end of the novel, following the close of the crime plot, Salander leaves Blomkvist in the cottage on the island of Hedeby. She is angry with him following his refusal to continue their casual sexual 
relationship asking instead for her friendship. Not sure why she is angry and towards whom her anger is directed, Salander's feelings for Blomkvist are ambiguous to her. Though she prefers to work alone, she had quite unexpectedly liked working with him, perhaps because he did not try to tell her how to live her life. Salander eventually returns to Blomkvist in the cottage. Unable to express her conflicting emotions, she changes into a t-shirt with the inscription: 'I can be a regular bitch. Just try me' (Larsson, 2008, pp. 462-63). She admits that she likes his company, and their conversation turns to Salander's special abilities as an investigator:

\footnotetext{
'That's just how it is. I know computers. I've never had a problem with reading a text and absorbing what it said.'

'Your photographic memory,' he said softly.

'I admit it. I just have no idea how it works. It's not only computers and telephone networks, but the motor in my bike and T.V. sets and vacuum cleaners and chemical processes and formulae in astrophysics. I'm a nutcase, I admit it: a freak.'

Blomkvist frowned. He sat quietly for a long time. Asperger's syndrome, he thought. Or something like that. A talent for seeing patterns and understanding abstract reasoning where other people perceive only white noise.
}

While unapologetically taking on the role of 'a regular [hard-boiled] bitch', as proclaimed on her t-shirt, her self-portrait as a 'savant' tech-nerd is revealing a shameful recognition of her own otherness, which Schwartz and Kaplan (forthcoming, p. 5) identify as a common trait in the female detectives; yet, I shall argue, while her uncommon 'savant' abilities are instrumental to solving the melodramatic crime plot, which will in turn help Blomkvist reestablish his 'trust capital' as a financial reporter, her 'freakishness' and appendant social dysfunctions are central to the novel's 'narrative of proximity', wherein her neurodiverse difficulties with establishing a meaningful interpersonal relation to Blomkvist represent a wider social diagnosis of the Swedish late-modern welfare state, and here Salander comes, paradoxically, to represent that which is absent from the wider community. The shame of inhabiting the position of the deviant other is, thereby, through the novel's sentimental narrative of Salander's Asperger's, as diagnosed by Blomkvist, and her relation to a nonimpaired companion, transferred onto the community, enveloping also the reader.

\section{The Crime Novel and the Autism 'Epidemic'}

The detective diagnosed with Asperger's or autism is not a novelty in recent popular culture; the diagnosis itself seems to be in tune with a widespread Zeitgeist. 'Autism,' according to Stuart Murray (2006, p. 25), '(including Asperger's syndrome, usually thought of as "highfunctioning" autism) currently occupies a place in the public consciousness that is akin to a 
phenomenon $[\ldots]$ we live in a time of an autism "epidemic". One reason for the ubiquity of narrative representations of autism, according to Murray, is that characters with autism appear proximate to or indistinguishable from the non-autistic, yet their behaviour and mannerisms deviate considerably from the norm, and have come to figure as the very 'personification of difference and otherness'.

While considered a diagnostic category at the time of Larsson writing The Girl with the Dragon Tattoo, in 2013 Asperger's syndrome was placed on a complex continuum with other pervasive neurodevelopmental disorders, such as autistic disorder, commonly referred to as ASD. These are 'broadly characterized by repetitive behaviours and varying degrees of difficulty in social interaction and verbal and nonverbal communication' (Badone, 2016, p. 477). The narrative appeal of fictional characters with autism is, according to Murray (2006, pp. 25-6), their apparent familiarity made uncanny by a condition that 'supposedly defies logic and understanding' yet enables 'the discussion of any number of issues that circulate in the popular understanding of the human condition'. Therefore, we should think of popular cultural representations of autism as less interested in the autistic individual herself (i.e. how autism may be considered a "way of being in the world that does not require "treatment" or "correction"”), instead presenting the autistic character as a reflection of the non-autistic world, as being preoccupied with 'an understanding of supposedly core human concerns, which are seen to inform and enrich the non-disabled and which work towards what [Lennard J.] Davis terms "the construction of normalcy" (Murray, 2008, pp. 14, 23). In the case of The Girl with the Dragon Tattoo, Salander's relationship with Blomkvist and her Asperger's 'diagnosis' is used as a sentimental allegory for a dysfunctional society (where 'men hate women' and sexual exploitation has become the norm) in need of developing social and interpersonal trust.

The 'ontological difference' between the neuro-diverse and the 'neuro-normal' central to autism-fictions, is dramatized, Murray (2006, pp. 27-8) argues, by placing 'the individual with autism in relation to the depiction of an individual with ostensibly typical nonimpaired behaviour' thereby mediating 'an idea of the human by a refractive comparison of the two'. In the Anglo-American novels and films discussed by Murray this relationship often hinges on what he calls the "“sentimental savant", a figure who displays the supposed savant abilities of the autist, especially in the realms of creativity and an understanding of supposedly core human concerns, that are seen to inform and enrich the nondisabled'.

Just as Asperger's was commonly perceived an impairment predominantly if not exclusively found in men, so the representation of autistic individuals in fiction and popular 
culture, particularly in the Anglophone world, has mostly featured male protagonists. Murray's cases are therefore also exclusively English-language narratives, where autistic behaviour features in discussions of contemporary masculinity, where for instance, contemporary films make 'moral or sentimental points about masculinity and, frequently, family, and they do so largely through the use of specific genre-based narratives, especially melodrama' (Murray, 2006, p. 28). While the popular representations in crime fiction of neuro-diverse characters must be understood as involving 'a fundamental misapprehension of the actual nature of autism', as Murray (2006, p. 29) argues, the deviant female detectives in Scandinavian crime fiction provide 'contemporary sentimental' storylines wherein feminine neuro-diversity becomes a paradoxical figure with which to imagine how meaningful and affective relationships may be built on interpersonal trust.

Salander's personal history of traumatic 'othering' and violation does not suggest that she will ever find it easy to build trusting relationships with 'men who hate women'(as the Swedish title points out). As a victim of sexual abuse and a patriarchal welfare state, she has good reason to distrust the men she encounters. The novel's sentimental narrative, however, suggests that a few male characters, such as Palmgren and Blomkvist, may ultimately allow Salander to relate to others without the shame associated with her 'diagnosis'. In the scene where Mikael considers whether Salander has Asperger's, he, like Palmgren before him, asks Salander for her friendship defined as a relationship built on mutual respect and trust, and, importantly, a relationship she can choose to enter freely. As the popular cultural understanding of Asperger's intimates, Salander is struggling to understand Blomkvist's proposal, as she still lacks the necessary interpersonal awareness; yet it is crucial for the subsequent parts of the trilogy that Salander is exposed to affective strategies, which may foster interpersonal relationships and positive change enabling her to live as an independent individual with a diagnosis in society.

\section{Diagnosing Saga Norén}

While the link between a neurodiverse diagnosis and critique of the contemporary welfare state is part of Salander's sentimental narrative, intimating that the moral corrosion of the welfare state's ability to provide for the wellbeing of a young woman has led to her social dysfunction and distrust in others, it is still a narrative of proximity that aligns the female neurodiverse investigator with the female victim(s). As a revenge narrative, The Girl with the Dragon Tattoo is fundamentally different from the four-season TV-police procedural Broen/Bron (The Bridge), where the deviant detective is a representative of the state, and one 
whose implicit diagnosis prevents her from acting outside the protocols of the law, leading her to situations where she will have to sacrifice her relationships with unimpaired partners to uphold the moral integrity of the law and the state.

On top of being a hardboiled female detective whose behaviour transcends the norms traditionally associated with her gender, Saga Norén too is a social outsider who 'suffers' from an inability to respond empathetically to anyone she gets in contact with: she asks inappropriate questions, shows little concern for other people's feelings and is neurotically following rules and regulations to the dismay of her laidback and sociable Danish colleague Martin Rohde in the first season of the serial. Her lack of social skills emphasises her deviance from the norm, but a deviance ironically portrayed as necessary for protecting societies against border-crossing crimes, which effortlessly criss-cross the Öresund Bridge connecting Denmark and Sweden, crimes that constantly blur the borders between the social and the individual: In season one, what at first appears to be a case of a serial 'truth terrorist' on a mission to avenge social injustices, turns out to be a disturbed former partner's personal vendetta against Rohde for ruining his marriage. In the following season, a case of politically motivated serial eco-terrorism turns out to involve a disturbed man's erotic desires for his dying sister and a plot to strengthen the stock value of a medical company; and in season three, what at first appears to be serial killings of civil-rights activists motivated by a rightwing commentator turns out to be the result of a young man's carefully planned revenge against his biological father and those who had wronged him as a child growing up in foster homes. In the final season the pattern is repeated when a brutal murder of the head of the Danish immigration board, suspected to involve a left-wing radical terrorist group, turns out to be linked to a son's revenge over the individuals who had failed to prevent the killing of his father.

The larger world of social insecurities linked to the globalized, neoliberal state is the smokescreen behind which ancient crime themes of revenge and jealousy leave a wake of broken, dysfunctional families. It is central to the series that the investigations' revelation of the personal and familial motives behind the crimes are 'proximate' to the detectives' personal conflicts. As the serial progresses, Saga Norén appears increasingly implicated in her own traumatic family history, and her two Danish partners, both of whom are familymen, are either failing to keep their families together or are living in a drugs-infused limbo with the ghosts of a wife and young children, who had mysteriously disappeared.

The serial begins its first season on the otherwise invisible border, half-way across the Öresund Bridge, where a body has been placed; or, as it turns out, two bodies. Mirroring the 
transnational location of a near-borderless region in the wider Nordic Passport Union, where one Scandinavian nation merges into the other, the severed dead bodies of two women, a Malmö politician and a Copenhagen prostitute, have been joined to form an apparently intact body lying astride national and social boundaries. The location of the crime scene in the border zone between two nations on the iconic bridge demands a cross-national investigation, where the two detectives must collaborate, overcome personal, cultural and linguistic differences, and, importantly, constantly criss-cross the bridge in order to match a killer who respects no borders.

The symbolic gesture and spectacular arrangement of the crime scene is the modus operandi of an elusive serial killer, who sees himself as a vigilante 'protector of the truth'. Through websites and the press, he proclaims that his killings are motivated by a desire to attract attention to the lack of care and social justice for the marginalized and dispossessed in society such as the mentally ill, the homeless, prostitutes and drug addicts. In this sense, narratives about lone 'truth terrorists' are always troubling symptoms or 'narratives of proximity', prompting the representatives of the law, readers and viewers by proxy, to confront their own collective responsibility for the corrosion of personal and societal bonds in society.

As Larsson's The Girl with the Dagon Tattoo employs statistics about men's violence against women as attention-gripping 'authenticity effect', so does the 'truth terrorist' in The Bridge refer to actual reports about crime and social inequality to justify his actions. In a recorded message to the police, he takes responsibility for the murders of the two women with the statement: 'Our part of the world would be wonderful if we solved our problems. I would like to point out five in particular. The women on the bridge are just the beginning' (s.1, ep.1). In the following episode, he calls attention to a series of 'facts' established in The Swedish Crime Survey 2007 and in a survey among socially marginalized groups in Denmark conducted by the National Institute of Public Health and the Council for Socially Marginalized People. To the terrorist, these surveys demonstrate that even in the most egalitarian of countries not everyone is 'equal before the law': crime investigations target disproportionally marginalized groups, whose health and wellbeing continue to deteriorate.

These reports do indeed corroborate the killer's social critique as they document deepening social inequalities. The Bridge is explicit about its welfarist egalitarianism, though it does not in the end endorse the vigilantism of the 'truth terrorist'. He eventually turns out to have misled the detectives and the public with his social agenda in order to pursue a covert personal vendetta. Instead, it is Norén's savant abilities, her naivety about social forms, her 
rationality, objectivity and her inability to speak nothing but the truth, which makes her an ideal protector of the law and the embodiment of the incorruptible, egalitarian welfare state.

Her role as protector of social coherence and her proximity to the terrorist is humorously demonstrated when she questions the murdered politician's bereaved husband. Norén asks him whether his wife was in any way threatened or had upset anyone lately. The only thing he can think of is that she wanted to charge for library loans and that some disapproved. Norén's prompt reply is: 'That's foolish', and she elaborates: 'Reading becomes a money matter. Social differences will grow.' It is, however, as she says, unlikely that library fees were the cause of her death.

Saga Norén is presented as the representative of the traditional egalitarian values of the 'people's home'. When four wealthy investors are summoned to the police station in season one to discuss the possibility of paying a ransom as demanded by the 'truth terrorist', Norén interjects that they should not expect them to pay, they are only used to stockpiling money and have no social conscience (s.1, ep.3). In the same season, the killer attempts to diverge the investigation by taking on the issue of immigrants being penalised harder by the courts. When the chief of police presents the case as relating to failed integration policies supported by statistics, Norén is able to go beyond the statistics to consider unethical motivations by declaring that the society's failure to act reveals that 'we don't want it to succeed'. 'Anyway,' she continues, with a further intimation of her awareness of complex personal motivations in others, 'all of this doesn't matter, because this is personal' (s.1, ep.6).

From the very beginning of the series, the apparently socially dysfunctional representative of the state is the one who speaks up for the welfare state and its egalitarianism. Before we know that the crimes she and Rohde are investigating are motivated by social indignation, we have learnt that Norén, and with her the police, plays the role of an idealized guardian of the incorruptible, rational and socially just state. When the self-proclaimed 'truth terrorist' in the end turns out to have used his militant social critique as a red herring, Norén's neurodiverse lack of empathy, her disinterestedness and unwavering dedication to the letter of the law, makes her incorruptible and without personal interest beyond solving the case and catching the criminal. However, they would not have been able to catch the killer without her uncharacteristic subtle awareness of the other's 'feelings' or motivations.

Like Salander, Saga Norén is a borderline character operating not only on geographical and social borders but also on the borders of what may be understood as 'normalcy'. Her story is a 'narrative of proximity', in Keen's (2007, p. 10) definition, 
wherein the protector of the state comes uncomfortably close to its threatening other, 'lack of empathy spells social problems' and 'lacking empathy often correlates with sociopathic behaviour'. That the series explores the border between Norén's neurodiversity and the perpetrator's is further emphasized when, in the first season, the police have asked a forensic psychologist for a profile of the killer. The profiler determines that the perpetrator is single, focused, successful, has clearly defined targets and is good at planning, but when Saga relates this to her superior, he believes she is talking about herself (s.1, ep.3). The series suggests that in order to deal with criminals in the post-welfare state, its representative has to be proximate to the deviant, anti-social criminals with the borders becoming increasingly blurred between the serial detective and the serial killer: To operate ethically in a society with wayward morals and lack of care, the detective has herself to deviate from the norms of the community.

However, we could also understand Saga Norén's abnormal inability to set personal and familial motives above the state, in Bruce Robbins's perspective, as

\footnotetext{
a refusal of that kind of "normal" social relationship that would ordinarily permit and even encourage state corruption: favoritism, cronyism, collusion with private economic interests, and so on. These are exactly the charges that Nordic noir is usually taken to be levelling at the welfare state.
}

These are also the charges the 'truth terrorist' is pointing out as reasons for his killings. As such, the deviant detective is a hero of the welfare society, as she effectively dispels her own bonds of dependence associated with the family, which in The Bridge is presented as a source of violence and vengeance. We should of course ask, as Robbins (2015) does, what it says about the state that 'contemporary Scandinavian crime fiction chooses to represent it by means of such a figure.' 'In other words,' Robbins points out, 'from one perspective the unsocialized women may represent a problem, but from another perspective she represents the solution to a problem.'

Following McHugh (2018, p. 546), we need to consider a more refined understanding of neurodiversity and its relation to empathy and ethics to be able to tell apart the neurodiverse detective from the 'monstrous' killer. In her view, although Norén is subtly aligned with the serial killer in season one 'psychopaths and people with ASD differ in their empathetic capacities' based on two functional axes: accurate recognition of other's feelings (cognitive function) and appropriate response to those feelings (affective function)'. Drawing on the work of Simon Baron-Cohen, McHugh points out that while psychopaths are often 'astute readers of others' feelings' their 'affective or subjective response is inappropriate, 
self-serving, or non-existent', while people on the autism spectrum 'have compromised cognitive function; they cannot read or recognize others' feelings', yet 'their affective responses to others' feelings, once they understand what they are, are highly functional. They do care and can care deeply.' It is precisely Norén's ASD, her 'compromised ability to emphasize', that results in her need to 'systematize to an extraordinary degree', leading her to be, what McHugh (2018, pp. 547-548) calls, 'super-moral': 'While Saga has trouble anticipating, reading, and understanding the social cues given off by others, when she is prompted or logically discerns someone's feelings, she responds appropriately'. Her superior investigative abilities, particularly on this case, and her 'superior ethics derive from a "felt knowledge" where ASD proclivity for systems and rules fosters her capacity for affective empathy'. McHugh's reading allows us to see how the deviant detective in The Bridge is being used not to approximate the detective to the killer, as their capacities for empathy are radically different, but instead to approximate the detective to communal values also shared in Scandinavian 'people's homes'.

A curious aspect of the series' presentation of the deviant detective is the fact that at no point is Saga Norén explicitly diagnosed or ASD even mentioned; still, her behaviours, facial expressions and the responses she incites in her aghast or amused co-workers all point to popular perceptions of Asperger's syndrome or autism. It is as such an unlikely female deviant hero that she has been widely diagnosed by viewers, according to an article on BBC News (Townsend, 2015):

\begin{abstract}
she is lauded not just because she is a leading character with the condition, but - more unusually because she is a woman with it. She is blunt, doesn't understand jokes and struggles to build relationships. She strips down to her underwear to get changed in the office without embarrassment, and asks and answers questions with often excruciating honesty. 'Would you like the recipe?' asks her dinner host. 'No, thanks, it wasn't tasty,' comes her reply. While the writers of The Bridge have never confirmed that Saga has Asperger syndrome [...] it has been generally assumed to be the case. Sofia Helin, the actress who plays her, has regularly referred to it in interviews. She researched the condition before filming started and has been sent letters and fan mail from people with the condition, as well as from the Swedish Asperger society.
\end{abstract}

While it is discernible from the portrayal of Saga Norén that she conforms to popular perceptions of Asperger's, the 'refusal' to diagnose the detective allows the series to explore a wider spectrum of deviance, where the 'ontological difference' between the neurodiverse and the 'neuro-normal' is blurred, and where rigid perceptions of empathy and interpersonal trust are challenged.

While Norén's lack of social skills dominate the first season, she becomes increasingly aware of her own difference and explores strategies for affective empathy (how to respond appropriately to another's emotions) as the series progresses, mainly prompted by 
her relations to male non-impaired colleagues. It is centrally Saga Norén's personal story that forms the series' sentimental narrative. As part of her strategy to develop ways to understand the personal motivations of the killers and other people around her, Saga Norén actively uses her partners as guides and mirrors - though they are not always reliable as they are incapable of seeing problematic patterns in their own behaviours. Rohde, for instance, possesses excellent social skills and has a flirtatious nature that makes him much liked among colleagues; however, these are also character traits that result in the breakup of his own and others' families, including the killer's.

That Saga Norén is left undiagnosed in the series allows us to more freely perceive her otherwise recognizable neurodiversity as less abnormal when contrasted to her nonimpaired colleagues. Their developing relationships do not suggest that Saga Norén's neurodiversity is simply signifying a lack that disables her ability to form and maintain healthy relationships. Instead, her awareness of her own difference and her lack of social skills ('empathic interaction with other people is not my strong side' [s.3, ep.8]) prompts her to 'interrogate' her partners about their private lives, their motivations and affective responses, partly to build her own capacity for affective empathy and partly to allow her to understand successfully the private motivations of the falsely 'socially conscious' killers.

Furthermore, by withholding a medical diagnosis as part of the narrative, we are also invited to 'read' Saga Norén's condition as caused by her experiences and therefore as an expression of a wider human or social condition. In season three she explains to her partner that the reason why she never lets people get close to her is that everyone has left her. In the context of this season, it again makes her experience similar or proximate to her partner's (who is still traumatised by the loss of his wife and two children) and the serial killer's (who is taking revenge against his father and the social system who abandoned him as a child). Saga Norén's accumulated losses drive her to an attempted suicide in the final season. She is only saved by her partner who pleads with her to help him find his lost children - and at the emotional climax of her personal story, she chooses companionship.

Her capacity to care for others with whom she is establishing trusting relationships without immediate personal gain is in the end what disassociates the deviant detective from the ills that have overwhelmed the welfare state (gender inequality, violence, distrust, revenge and lack of social care). It is in the end not capacities associated with her gender that allow her to empathise and treat the ills of others and herself; instead, they are learned capacities for affective empathy gained from her application of a neurodiverse proclivity for 
rule-based justice and social equality to accumulated 'felt knowledge' from interactions with non-impaired others.

\section{Conclusion}

In line with critics such as Rita Felski, I believe that literature offers us important 'social knowledge'. Crime novels and TV series are not mere symptoms of deeply hidden social realities, neither are they predominantly escapist or mindless entertainment. They are 'useful' because they engage us as readers and viewers, they invite us in and may potentially transform us 'by drawing us into certain attitudes, postures, and modes of engagement' with the social conditions and imaginations we share (Felski, 2013, p. xii). The deviant female detectives in Nordic Noir, discussed in this chapter, engage us particularly through their dramatization of how social and felt knowledge, central both to an ASD diagnosis and to the development of trusting interpersonal and societal relationships, need to be re-articulated in the post-welfare state.

In The Girl with the Dragon Tattoo, Salander's 'diagnosis', her social deviance, points to a wider social dysfunction that needs (literary) treatment: trusting relationships between men and women, between the state and its citizens need mending in order to reestablish a just, egalitarian home for all its citizens. The social knowledge dramatized by Stieg Larsson through the socially impaired Salander figure shares a fundamental ethos with the The Bridge. Both narratives appear to use neurodiversity, and ASD in particular, not as a way to invoke the readers' and viewers' sympathies toward the protagonists, but instead as a way to engage the audience in explorations of the intimate, and sometime fraught, relationship between the state and the individual. Such 'social knowledge' is particularly relevant to the Nordic universal welfare states and their ethos of 'statist individualism'.

Against the commonly held belief that the universal welfare state inevitably undermines individual autonomy and freedoms, the central ethos of the 'Nordic model', in fact, helped to strengthen individual autonomy 'by freeing citizens from their family obligations as well as from the constraints of the market' (Hilson, 2008, pp.107-8). Apart from social trust, which has not waned with the expansion of the state, it is 'statist individualism,' 'a concept that captures the seeming paradox of an ethos that is based on a strong alliance between the state and the individual aiming at making each citizen as independent of his or her fellow citizens as possible,' that sets the Nordic welfare states apart from other societies (Berggren and Trägårdh, 2010, p.56; Trägårdh, 2012, p.41). The neurodiverse, 'othered' detective, her 'superior morals' and her use of 'felt knowledge' to 
build relationships and solve crime mysteries, wherein 'social' injustices are intimately linked to the personal, is, therefore, posturing as a wider challenge inherent to the maintenance of just, egalitarian societies, namely to pursue individual freedom and autonomy through others.

I have argued that the deviant detectives in Scandinavian crime fiction are presented within sentimental storylines that counterpart the melodramatic crime narratives of social dissolution and violent crime. These stories explore 'the pleasures and challenges of community', how to form meaningful relationships build on interpersonal trust across 'borders' and 'ontological differences', where Saga Norén, in particular, represents a perception of deviance not as a symptom of the post-welfare state (and the detective not its victim), but instead its treatment. If the supposed decline of the social state has resulted in a more violent, misogynist and individualized society, then, perhaps, only an equally antisocial detective can stem its tide. While such a perspective may appear persuasive, particularly from an anti-statist point of view, I argue that the detective's neurodiversity or deviance should instead be perceived as a narrative, sentimental and 'affective strategy' with which Scandinavian crime fiction engages audiences in negotiations of social responsibility, interpersonal trust and our reliance on a just, dispassionate state to stem the tide of perpetrators (and melodramatic crime stories) who merely use social conscience as a cover for personal gain (Felski 2008).

\section{Works Cited}

Agger, G., 2011. Emotion, gender and genre: Investigating The Killing. Northern Lights, 9,pp.111-125.

Badone, E., Nicholas D., Roberts W. and Kien P., 2016. Asperger's syndrome, subjectivity and the senses. Cult Med Psychiatry 40, pp.475-506.

Berggren, H. and L. Trägårdh, 2010. Pippi Longstocking: the autonomous child and the moral logic of the Swedish welfare state. In: H. Matsson and S-O. Wallenstein, eds. Swedish modernism: architecture, consumption and the welfare state. London: Black Dog, pp.50-65.

Broen/Bron, 2011, 2013, 2015, 2018. [TV programme]. Danmarks Radio, DR1.

Brovall, S., 2013. Tv-tendens: Vi er vilde med de følelseskolde 'mandekvinder'. Politiken Online, [online] 20. Sept. Available at < 
https://politiken.dk/kultur/medier/art5545617/Tv-tendens-Vi-er-vilde-med-def\%C3\%B8lelseskolde-mandekvinder> [Accessed 2 Aug. 2018].

Cassuto, L., 2009. Hard-boiled sentimentality: the secret history of American crime stories. New York: Columbia University Press.

Den som draber, 2011. [TV programme]. TV2 Danmark.

Felski, R., 2008. Uses of literature. Oxford: Blackwell.

Felski, R., 2013. Introduction. New Literary History, 44(4), pp.v-xii.

Forbrydelsen, 2007, 2009, 2011. [TV programme]. Danmarks Radio, DR1.

Guardian, 2012. Anatomy of a Scandi-Protagonist. The Guardian, 29. Dec. p.9.

Hilson, M., 2008. The Nordic Model: Scandinavia since 1945. London: Reaktion Books.

Keen, S., 2007. Empathy and the novel. Oxford: Oxford University Press.

Larsson, S., 2008. The girl with the dragon tattoo. Transl. by Reg Keeland. London: Maclehose Press.

Leffler, Y., 2013. Lisbeth Salander as a melodramatic heroine: emotional conflicts, split focalization, and changing roles in Scandinavian crime fiction. In: B. Åstrøm, K. Gregersdotter and T. Horeck, eds. 2013. Rape in Stieg Larsson's millennium trilogy and beyond. Houndmills: Palgrave, pp.51-66.

Marklund, L., 2011. The bomber. Trans. by N. Smith. London: Corgi.

McHugh, K. A., 2018. The female detective, neurodiversity, and felt knowledge in Engrenages and Bron/Broen. Television \& New Media, 19(6), pp.535-552.

Murray, S., 2006. Autism and the contemporary sentimental: fiction and the narrative fascination of the present. Literature and Medicine 25(1), pp.25-45.

Murray, S., 2008. Representing autism: culture, narrative, fascination. Liverpool: Liverpool University Press.

Plain, G., 2001. Twentieth century crime fiction: gender, sexuality and the body. New York: Routledge.

Robbins, B., 2015. The detective is suspended: Nordic noir and the welfare state. Post 45 , [online] Available at: < http://post45.research.yale.edu/2015/05/the-detective-issuspended-nordic-noir-and-the-welfare-state> [Accessed 2 Aug. 2018].

Rothstein, B., 2005. Social traps and the problem of trust. Cambridge: Cambridge University Press.

Scaggs, J., 2005. Crime fiction. London: Routledge. 
Schmidt, N., 2015. From periphery to center: (post-feminist) female detectives in contemporary Scandinavian crime fiction. Scandinavian Studies 87(4), pp.423-456.

Schwartz, C. and E. A. Kaplan, forthcoming 2018. The female detective as the child who needs to know. Saga Norén as an example of potent yet dysfunctional female detectives in contemporary Nordic noir. European Journal of Scandinavian Studies.

Stenport, A. W. and C. O. Alm, 2009. Corporations, crime, and gender construction in Stieg Larsson's The girl with the dragon tattoo: exploring twenty-first century neoliberalism in Swedish culture. Scandinavian Studies 81(2), pp.157-178.

Stougaard-Nielsen, J., 2017. Scandinavian crime fiction. London: Bloomsbury.

Svensson, P., 1999. Syndafallet. In: B. Eriksson, ed., 1999. I neonljusets skugga: den moderna kriminalhistorien. Lund: Boströms, pp.167-183.

Tapper, M., 2011. Snuten i skymringslandet: Svenska polisberättelser i roman och film 19652010. Lund: Nordic Academic Press.

Townsend, L., 2015. How The Bridge's heroine became a role model for women with autism. $B B C$ News, [online] 9. Dec. Available at: https://www.bbc.co.uk/news/disability34995327 [Accessed on 25 June 2018].

Trust Nordisk, n.d. Those who kill pressbook. [online] Available at: http://files.trustnordisk.com/files/ftpfiles/movies/TN31/public/docs/TWK Pressbook Final.pd f [Accessed 2 Aug. 2018].

Trägårdh, L., 2012. Mellem liberalisme og socialisme: om det særlige ved den nordiske model. Kritik 206, pp.40-50. 